\title{
Apparent ileal digestibility of amino acids in pig diets containing various sources of dietary fibre*
}

\author{
A. Antuszewicz ${ }^{1}$ and E. Święch \\ The Kielanowski Institute of Animal Physiology and Nutrition, \\ Polish Academy of Sciences \\ 05-110 Jabłonna, Poland
}

\begin{abstract}
The experiment was carried out in a cross-over design with 14 growing pigs fitted with a postvalvular T-ceacum (PVTC) cannula. Animals were fed on wheat-casein diets supplemented with 5\% of different dried fibre by-products: apple pulp, apple pectin, beet pulp, potato pulp, artichoke offals or cellulose (control). Apparent ileal digestibility of protein and amino acids in experimental diets were high, similar to the control diet, and not affected by inclusion of fibre by-product to the diet.
\end{abstract}

KEY WORDS: dietary fibre, amino acids, ileal digestibility, pigs

\section{INTRODUCTION}

Many fibrous by-products of fruits and vegetables industry may be used in animal nutrition as the potential source of dietary fibre. Dietary fibre is often recommended to young pigs since it stimulates the passage of digesta and the development of beneficial microflora and improves health of the digestive tract. However, it is difficult to predict possible effects of raw dietary fibre, such as different fibrous by-products from foodstuffs industry, on protein and amino acids digestion and absorption in the small intestine in young pigs. According to Li et al. (1994) and Schulze et al. (1995) fibre by-products included into the diet increase ileal losses of total protein and amino acids in pigs.

The objective of the study was to determine effects of the fruit and vegetable by-products, differing in origin and composition of dietary fibre, on apparent ileal digestibility of protein and amino acids when added to a highly digestible wheatcasein diet.

\footnotetext{
* Supported by $5^{\text {th }}$ Framework Programme (CRAFT-Profibre) and the State Committee for Scientific Research (Poland), Grant No. 2P06Z05727

1 Corresponding author: e-mail: a.antuszewicz@ifzz.pan.pl
} 


\section{MATERIAL AND METHODS}

\section{Fibre by-products and diets}

Six dried by-products orginating from different branches of food industry in Denmark, Spain and Poland were used. They comprised: potato pulp - the residuals after starch and protein extraction, apple pectin and apple pulp - the by-products of juice production, artichoke - the offals from artichoke canning, and sugar beet pulp - the residue after sugar extraction. Cellulose was used in the control diet as a fibre source.

Five percent of each product or cellulose was added to the diet containing, $\%$ : wheat 60 , casein 13 and soyabean oil 2 as main ingredients. The diets were supplemented with minerals and vitamins to meet Nutrient Requirement of Pigs (1993). Chromic oxide was included in the diets as the marker for the determination of protein and amino acids digestibility.

\section{Animals and experimental procedure}

The experiment was carried out with 14 male pigs of initial $22 \mathrm{~kg}$ body weight fitted with a post-valvular T-ceacum (PVTC) cannula (van Leeuwen et al., 1991). Experimental diets were fed twice daily in equal meals (08.00 and 20.00) according to a change-over design; each diet was given to six animals. Pigs were individually fed 2.8 times maintenance requirement for ME. After a 6-day addaptation period, the ileal digesta was collected for 3 days, for $12 \mathrm{~h}$ per day between meals, pooled and frozen until analysis.

\section{Analytical procedures}

Crude protein, ether extract, and crude fibre in by-products were analysed using standard methods (AOAC,1990). The content of ADF and NDF were determined with Fibertec System M by methods of Van Soest and Wine (1967) and Van Soest (1973). The soluble (SDF) and insoluble (IDF) dietary fibre were determined according to Asp et al. (1983). Amino acid compositions in the diets and the ileal digesta were determined using amino acids analyser Beckman 6300. Statistical analysis of results was performed using SPSS ver. 11.5

\section{RESULTS AND DISCUSSION}

Used by-products differed in crude protein, ether extract, ADF, NDF and SDF and IDF dietary fibre content (Table 1). The proportions of ADF were similar in apple pulp and artichoke offals while about twice as high as that in sugar beet and 
potato pulp. The NDF content was higher in the apple pulp than in remaining byproducts. The contents of SDF and IDF differed even to greater extent: the apple pectin had very high SDF content, while in remaining by-products prevailed ADF (Table 1), which were the lowest in apple pulp and artichoke offals.

Table 1. Chemical composition of fibre by-products, $\mathrm{g} \mathrm{kg}^{-1} \mathrm{DM}$

\begin{tabular}{lccccc}
\hline Item & $\begin{array}{c}\text { Apple } \\
\text { pectin }\end{array}$ & $\begin{array}{c}\text { Apple } \\
\text { pulp }\end{array}$ & $\begin{array}{c}\text { Sugar beet } \\
\text { pulp }\end{array}$ & $\begin{array}{c}\text { Potato } \\
\text { pulp }\end{array}$ & $\begin{array}{c}\text { Artichoke } \\
\text { offals }\end{array}$ \\
\hline Crude protein & 11.2 & 78.8 & 92.5 & 51.3 & 63.5 \\
Ether extract & 4.5 & 74.6 & 3.2 & 7.4 & 13.5 \\
Ash & 14.9 & 14.7 & 35.9 & 27.2 & 78.8 \\
Crude fibre & - & 327.9 & 196.7 & 205.2 & 290.3 \\
ADF & - & 440.0 & 236.1 & 262.5 & 451.3 \\
NDF & 3.6 & 561.6 & 490.4 & 462.3 & 448.1 \\
Soluble fibre (SDF) & 985 & 62 & 156 & 181 & 82 \\
Insoluble fibre (IDF) & 9 & 627 & 640 & 474 & 590 \\
\hline
\end{tabular}

Table 2. Apparent ileal digestibility of crude protein $(\mathrm{CP})$ and amino acids in pigs fed diets containing cellulose or various fibre by-products, $\%$ (mean $\pm \mathrm{SD}, \mathrm{n}=6$ )

\begin{tabular}{lcccccc}
\hline Item & Cellulose & $\begin{array}{c}\text { Apple } \\
\text { pectin }\end{array}$ & $\begin{array}{c}\text { Apple } \\
\text { pulp }\end{array}$ & $\begin{array}{c}\text { Sugar beet } \\
\text { pulp }\end{array}$ & $\begin{array}{c}\text { Potato } \\
\text { pulp }\end{array}$ & $\begin{array}{c}\text { Artichoke } \\
\text { offals }\end{array}$ \\
\hline CP & $82.9 \pm 1.0$ & $83.3 \pm 6.3$ & $82.2 \pm 0.7$ & $82.2 \pm 0.6$ & $82.0 \pm 0.9$ & $80.2 \pm 2.6$ \\
Lys & $87.8 \pm 1.0$ & $86.9 \pm 1.9$ & $87.2 \pm 0.4$ & $87.9 \pm 0.7$ & $87.0 \pm 0.8$ & $86.9 \pm 1.4$ \\
Met & $89.8 \pm 0.6$ & $88.4 \pm 1.6$ & $89.7 \pm 0.4$ & $90.3 \pm 0.7$ & $89.1 \pm 0.8$ & $89.3 \pm 0.6$ \\
Cys & $74.6 \pm 1.5$ & $70.8 \pm 2.9$ & $72.8 \pm 2.2$ & $74.4 \pm 1.5$ & $72.0 \pm 1.7$ & $72.5 \pm 2.7$ \\
Thr & $77.7 \pm 1.5$ & $76.3 \pm 3.0$ & $77.1 \pm 1.3$ & $77.6 \pm 1.0$ & $75.8 \pm 1.7$ & $76.6 \pm 2.7$ \\
Trp & $83.3 \pm 1.8$ & $81.6 \pm 2.6$ & $82.4 \pm 1.3$ & $83.2 \pm 1.5$ & $81.0 \pm 0.9$ & $82.0 \pm 2.2$ \\
Ile & $81.7 \pm 1.5$ & $81.0 \pm 2.7$ & $81.9 \pm 0.9$ & $81.4 \pm 0.8$ & $80.5 \pm 0.9$ & $81.0 \pm 1.5$ \\
His & $89.8 \pm 0.8$ & $88.6 \pm 1.5$ & $88.9 \pm 0.5$ & $87.4 \pm 0.5$ & $88.6 \pm 0.5$ & $88.8 \pm 1.2$ \\
Leu & $89.9 \pm 0.7$ & $89.0 \pm 1.5$ & $89.0 \pm 0.5$ & $89.6 \pm 0.5$ & $88.5 \pm 0.9$ & $88.6 \pm 1.0$ \\
Phe & $87.7 \pm 4.2$ & $89.9 \pm 1.5$ & $89.9 \pm 0.6$ & $91.4 \pm 0.3$ & $89.0 \pm 0.6$ & $89.7 \pm 0.9$ \\
Val & $83.9 \pm 1.0$ & $82.8 \pm 2.2$ & $83.1 \pm 0.8$ & $83.6 \pm 0.8$ & $82.8 \pm 0.7$ & $83.2 \pm 1.4$ \\
\hline
\end{tabular}

In spite of the differences in the chemical composition, none of the supplemented by-products affected the apparent ileal digestibility of protein and amino acids (Table 2). Protein digestibility was high and amino acids digestibility followed normal pattern being the lowest for threonine and cystine and the highest for methionine as showed by Święch and Buraczewska (2005).

Our data do not support the results of Dierick et al. (1983) who found that inclusion of 5\% pectin to a semi-purified diet markedly decreased ileal digestibility of protein and amino acids. Mosenthin et al. (1994) also reported significant reduction in the apparent digestibility of protein and amino acids in pigs given 
semi-purified diet with 7.5\% pectin. However, Den Hartog et al. (1988) did not found any effect when $5 \%$ pectin was included in the diet formulated from natural ingredients such as maize, barley and soyabean meal. It may therefore suggest that the effect of pectin on digestion processes depends on diet composition.

\section{CONCLUSIONS}

The supplementation of pig diets with $5 \%$ of fruit and vegetable fibre byproducts of different composition or with cellulose does not impaire the total protein and amino acid digestion in the small intestine. It indicates, that the byproducts may be used in young pig nutrition.

\section{REFERENCES}

AOAC, 1990. Association of Official Analytical Chemists, Official Methods of Analysis. 15 Edition. Arlington, VA

Asp N.G., Johansson C.G., Hallmer H., Sijestrom M., 1983. Rapid enzymatic assay of insoluble and soluble dietary fibre. J. Agr. Food Chem. 31, 476-482

Dierick N.A., Vervaeke I.J., Demeyer D.J., Deucuypere J.A., 1989. Approach to the energetic importance of fibre digestion in pigs. I. Importance of fermentation in the overall energy supply. Anim. Feed Sci. Tech. 23, 141-167

Hartog L.A., Huisman J., Thielen W.J.G., Schayk G.H.A., Boer H., Van Weerden E.G., 1988. The effect of including various structural polysaccharides in pig diets on ileal and faecal digestibility of amino acids and minerals. Livest. Prod. Sci. 18, 157-170

Li S., Sauer W.C., Hardin R.T., 1994. Effect of dietary fibre level on amino acid digestibility in young pigs. Can. J. Anim. Sci. 74, 327-333

Nutrient Requirement of Pigs. Nutrition Value of Feedstuffs (in Polish), 1993. The Kielanowski Institute of Animal Physiology and Nutrition (Editor), Jabłonna (Poland)

Schulze H.P., van Leeuven P., Verstegen M.W.A., van den Berg J.W.O., 1995. Dietary level and source of neutral detergent fibre and ileal endogenous flow in pigs. J. Anim. Sci. 73, 441-448

Święch E., Buraczewska L., 2005. True ileal digestibility of amino acids of pea seeds and soyabean products estimated in pigs, rats and in vitro. J. Anim. Feed Sci. 14, 179-191

Van Leeuwen P., van Kleef D., van Kempen G.J.N., Huisman J., Verstegen M.W.A., 1991. The post valve T-caecum consultation technique in pigs applicated to determine the digestibility of amino acid in maize, groundnut and sunflower meal. J. Anim. Physiol. Anim. Nutr. 65, 183-193

Van Soest P.J., 1973. Collaborative study of acid detergent fiber and lignin. J. Assn. Off. Anal. Chem. 56, 513-530

Van Soest P.J., Wine R.H., 1967. Use of detergents in the analysis of fibrous feeds. IV. Determination of plant cell wall constituents. J. Assn. Off. Anal. Chem. 50, 50-55 